NASA/TM-2001-210816

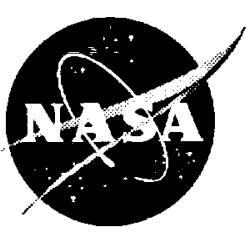

\title{
Thermal Fatigue and Fracture Behavior of Ceramic Thermal Barrier Coatings
}

Dongming Zhu and Sung R. Choi

Ohio Aerospace Institute, Brook Park, Ohio

Robert A. Miller

Glenn Research Center, Cleveland, Ohio 
Since its founding, NASA has been dedicated to the advancement of aeronautics and space science. The NASA Scientific and Technical Information (STI) Program Office plays a key part in helping NASA maintain this important role.

The NASA STI Program Office is operated by Langley Research Center, the Lead Center for NASA's scientific and technical information. The NASA STI Program Office provides access to the NASA STI Database, the largest collection of aeronautical and space science STI in the world. The Program Office is also NASA's institutional mechanism for disseminating the results of its research and development activities. These results are published by NASA in the NASA STI Report Series, which includes the following report types:

- TECHNICAL PUBLICATION. Reports of completed research or a major significant phase of research that present the results of NASA programs and include extensive data or theoretical analysis. Includes compilations of significant scientific and technical data and information deemed to be of continuing reference value. NASA's counterpart of peerreviewed formal professional papers but has less stringent limitations on manuscript length and extent of graphic presentations.

- TECHNICAL MEMORANDUM. Scientific and technical findings that are preliminary or of specialized interest, e.g., quick release reports, working papers, and bibliographies that contain minimal annotation. Does not contain extensive analysis.

- CONTRACTOR REPORT. Scientific and technical findings by NASA-sponsored contractors and grantees.
- CONFERENCE PUBLICATION. Collected papers from scientific and technical conferences, symposia, seminars, or other meetings sponsored or cosponsored by NASA.

- SPECIAL PUBLICATION. Scientific, technical, or historical information from NASA programs, projects, and missions, often concerned with subjects having substantial public interest.

- TECHNICAL TRANSLATION. Englishlanguage translations of foreign scientific and technical material pertinent to NASA's mission.

Specialized services that complement the STI Program Office's diverse offerings include creating custom thesauri, building customized data bases, organizing and publishing research results ... even providing videos.

For more information about the NASA STI Program Office, see the following:

- Access the NASA STI Program Home Page at http://www.sti.nasa.gov

- E-mail your question via the Internet to help@sti.nasa.gov

- Fax your question to the NASA Access Help Desk at 301-621-0134

- Telephone the NASA Access Help Desk at 301-621-0390

- Write to: NASA Access Help Desk NASA Center for AeroSpace Information 7121 Standard Drive Hanover, MD 21076 
NASA/TM-2001-210816

\section{Thermal Fatigue and Fracture Behavior of Ceramic Thermal Barrier Coatings}

Dongming Zhu and Sung R. Choi

Ohio Aerospace Institute, Brook Park, Ohio

Robert A. Miller

Glenn Research Center, Cleveland, Ohio

Prepared for the

25th Annual International Conference on Advanced Ceramics and Structures sponsored by the American Ceramic Society

Cocoa Beach, Florida, January 21-26, 2001

National Aeronautics and

Space Administration

Glenn Research Center 


\section{Acknowledgments}

This work was supported by NASA Ultra-Efficient Engine Technology (UEET) Program. The authors are grateful to George W. Leissler and Sandra L. Leissler of Dynacs Engineering, Inc. at NASA Glenn Research Center for their assistance in the preparations of plasma-sprayed $\mathrm{ZrO}_{2}-8 \mathrm{wt} \% \mathrm{Y}_{2} \mathrm{O}_{3}$ coatings and the metallographic specimens.

Available from

NASA Center for Aerospace Information 7121 Standard Drive Hanover, MD 21076
National Technical Information Service 5285 Port Royal Road Springfield, VA 22100

Available electronically at http://gltrs.grc.nasa.gov/GLTRS 


\title{
THERMAL FATIGUE AND FRACTURE BEHAVIOR OF CERAMIC THERMAL BARRIER COATINGS
}

\author{
Dongming Zhu and Sung R. Choi \\ Ohio Aerospace Institute \\ Brook Park, Ohio 44142 \\ Robert A. Miller \\ National Aeronautics and Space Administration \\ Glenn Research Center \\ Cleveland, Ohio 44135
}

\begin{abstract}
Thermal fatigue and fracture behavior of plasma-sprayed ceramic thermal barrier coatings has been investigated under high heat flux and thermal cyclic conditions. The coating crack propagation is studied under laser heat flux cyclic thermal loading, and is correlated with dynamic fatigue and strength test results. The coating stress response and inelasticity, fatigue and creep interactions, and interface damage mechanisms during dynamic thermal fatigue processes are emphasized.
\end{abstract}

\section{INTRODUCTION}

Ceramic thermal barrier coatings (TBCs) have received increasing attention for advanced gas turbine engines. The future TBC systems will be more aggressively designed for the thermal protection of engine hot section components, thus allowing significant increase in engine operating temperatures, fuel efficiency and engine reliability. However, the increases in engine temperature and heat flux can raise considerable coating durability issues. The development of next generation advanced TBCs will greatly rely on the better understanding of the coating behavior and failure modes under the high temperature, high thermal gradient cyclic conditions.

Critical coating properties affecting the TBC life, such as ceramic sintering and creep, and thermal conductivity change kinetics at high temperatures, have been previously addressed [I-5]. Fundamental TBC materials properties including deformation, cyclic fatigue, creep and fracture behavior have also recently been characterized [6-12]. This present paper is primarily focused on thermal fatigue properties of plasma-sprayed TBC systems under temperature and stress gradients that can be encountered in advanced engine systems. In particular, quantitative crack propagation in a TBC system is investigated under laser heat flux thermal cyclic loading. The coating life prediction methodologies can be established based on the materials response and failure mechanisms observed under the high-heat-flux tests.

\section{EXPERIMENTAL MATERIALS AND METHODS}

Air plasma-sprayed (APS) $\mathrm{ZrO}_{2}-8 \mathrm{wt} \% \mathrm{Y}_{2} \mathrm{O}_{3}$ thermal barrier coatings were used for the coating thermal fatigue-crack propagation study. In this work, $25.4 \mathrm{~mm}$-diameter and $3.2 \mathrm{~mm}$ thick nickel base superalloy specimens were used as substrates. This button specimen configuration, which was previously used for coating thermal conductivity studies [5,13], is ideal 
for investigating the coating delamination crack propagation because the coating conductivity change is sensitive to the delamination cracks. The test coating system consists of an air plasmasprayed $\mathrm{ZrO}_{2}-8 \mathrm{wt} \% \mathrm{Y}_{2} \mathrm{O}_{3}$ top coating (typical thickness range about 127 to $200 \mu \mathrm{m}$ ) and an intermediate low pressure plasma-sprayed NiCrAlY bond coat (thickness about $120 \mu \mathrm{m}$ ), plasmasprayed on the button specimen substrates. A through-thickness hole, with either $1 \mathrm{~mm}$ - or $2 \mathrm{~mm}$ diameter, was drilled in the center of the substrate by the electro-discharge machining (EDM). The central substrate hole thus prepared was able to successfully initiate a controlled coating delamination crack during initial laser thermal cyclic loadings.

A high power $\mathrm{CO}_{2}$ laser was used to test the TBC specimens under high temperature, high thermal gradient cyclic conditions, thus providing the necessary thermal fatigue loading for advancing the pre-initiated delamination cracks within the ceramic coatings near the ceramic/metal interface. A uniform laser power distribution was achieved over the specimen coating surface by using an integrating ZnSe lens combined with the specimen rotation. A description of the laser test rig system and the general approaches to testing the TBCs have been described elsewhere [4,5]. For this work, low to medium heat fluxes of 60 to $100 \mathrm{~W} / \mathrm{cm}^{2}$ were used depending on the specimen coating thickness. Initial ceramic surface temperature was set at approximately $1287^{\circ} \mathrm{C}$. Either 10 or $20 \mathrm{~min}$ heating/cooling cycles were used for the laser thermal gradient cyclic tests. During the test, the ceramic surface temperature was measured by an $8 \mu \mathrm{m}$ infrared pyrometer. The back surface of the metal substrate was measured by both a two-color infrared pyrometer and a calibrated $8 \mu \mathrm{m}$ pyrometer. The spot size (diameter) of the $8 \mu \mathrm{m}$ pyrometer was 8 to $10 \mathrm{~mm}$. The simultaneous measurements of the surface and backside temperatures provide transient heating temperature information, which is especially important for the cracked coating specimens. The spatially weighted-average temperature information at coating surface in the presence of a delamination crack was calibrated in-situ with a high sensitivity camera under the given crack sizes, and ex-situ with a blackbody calibration furnace with various aperture sizes.

\section{EXPERIMENTAL RESULTS AND DISCUSSION}

\section{Effective Thermal Conductivity and Delamination Crack Propagation}

The laser thermal fatigue and crack propagation study is based on a modified thermal conductivity test. In this test, the surface temperature and metal backside temperature of a precracked TBC specimen are continuously measured during the laser cyclic thermal fatigue test. The nominal, or effective thermal conductivity of the ceramic coating can thus be determined as a function of the laser cycle number. The effective thermal conductivity at any given cycle contains valuable information about the advancing delamination crack in the coating in laser thermal cyclic loading. Fig. 1 shows typical test results for a $127 \mu \mathrm{m}$-thick, pre-cracked TBC specimen under the laser cyclic loading. It can be seen that the surface temperature increased continuously due to the crack initiation and propagation. The metal backside temperature and the predicted metal/ceramic interface temperature, however, remained relatively constant or a slight decreasing trend. The measured ceramic coating conductivity initially increased and decreased with further increasing the testing time and cycle number. The initial rise in the measured conductivity is attributed to the ceramic sintering effect. It is also noted that a sudden drop in thermal conductivity that is corresponding to a large surface temperature jump, was observed at about $30 \mathrm{hrs,} \mathrm{suggesting} \mathrm{a}$ coating spallation event occurred at that time.

The measured ceramic thermal conductivity $k_{\text {measured }}$ for a pre-cracked TBC specimen can be expressed as

$$
k_{\text {measured }}=k_{\text {int act }}+k_{\text {cracking }}
$$


where $k_{\text {in act }}$ is the thermal conductivity of non-cracked TBC specimen, which typically increases with time or cycle number due to the ceramic sintering effect, and $k_{\text {crecking }}$ is the thermal conductivity reduction due to the coating cracking effect. The $k_{\text {int } x \text { c }}$ can be estimated from the previously reported coating property data under the current test conditions $[3,14]$. From the $k_{\text {int art }}$ and measured $k_{\text {measured }}$ data, the $k_{\text {cracking }}$ can be obtained, as shown in Fig. 1. The $k_{\text {cracking }}$ showed a monotonic decreasing trend that corresponds to the delamination crack growth in the TBC system during laser thermal cycling. Fig. 2 shows similar test results of a TBC specimen with a $2 \mathrm{~mm}$ hole in the substrate. Again, the change in the specimen effective thermal conductivity clearly quantified the evolution of the crack propagation and coating spallation behavior. The coating propagation process has also been confirmed independently by a high sensitivity video camera [15].

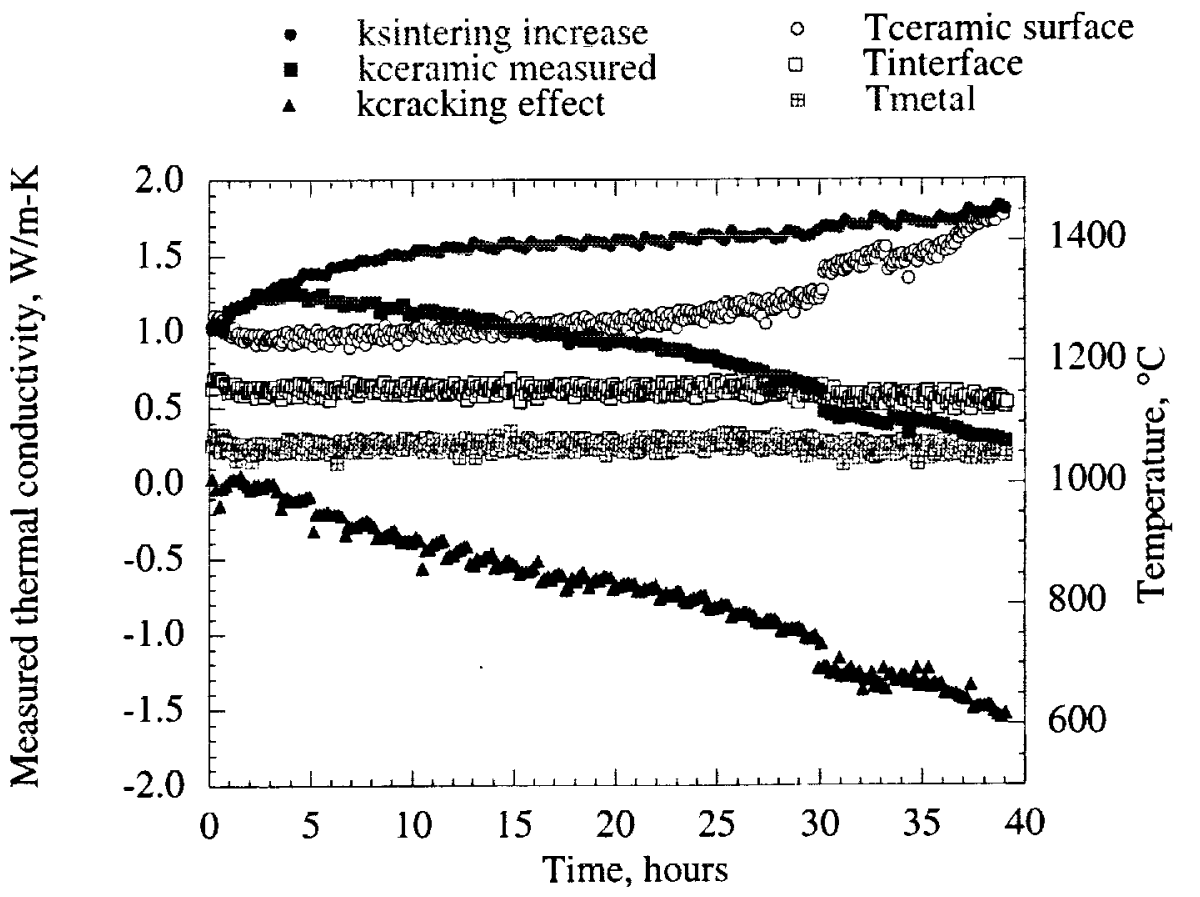

Fig. 1 Typical laser thermal fatigue test results of a $127 \mu \mathrm{m}$-thick, precracked TBC specimen showing the coating temperature and thermal conductivity changes as a function of cycle number under $10 \mathrm{~min}$ heating and $2 \mathrm{~min}$ cooling laser cycling. The ceramic surface temperature increases and the metal backside temperature slightly decreases as the delamination crack is initiated and propagated. The effective ceramic coating conductivity shows an initial increase due to the coating sintering, and then a decrease due to the crack propagation. A large conductivity drop during the test indicates the coating spallation. 


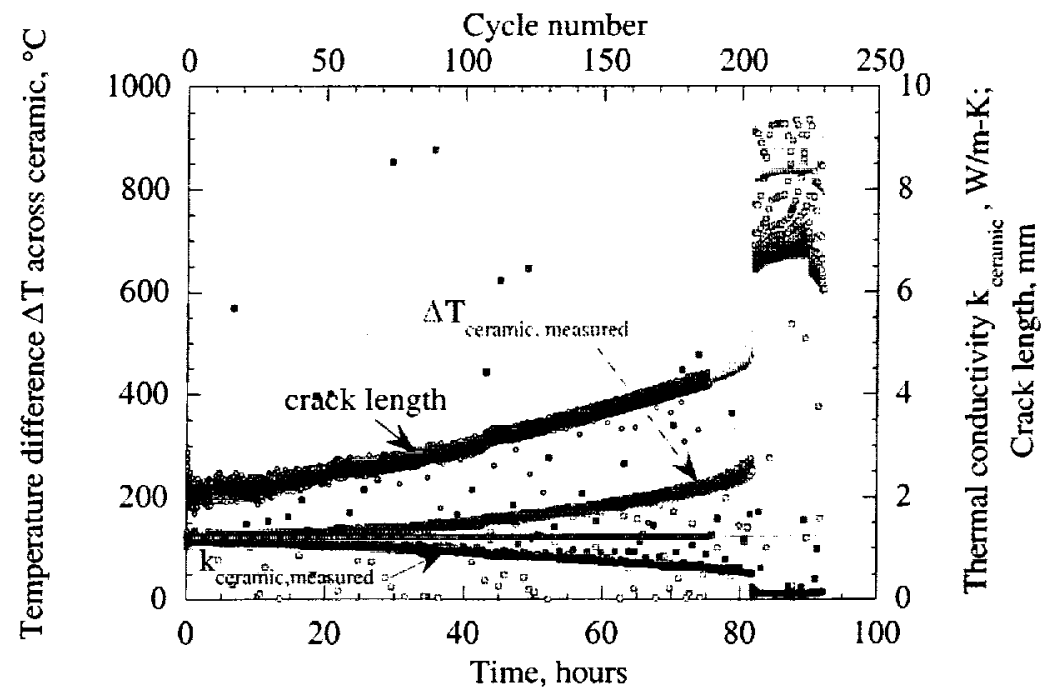

Fig. 2 The laser thermal fatigue test results of a $0.2 \mathrm{~mm}$-thick TBC specimen with a $2 \mathrm{~mm}$ hole in the substrate when exposed to 20 min heating and 4 min cooling laser cycling. A close relationship between the coating thermal conductivity and delamination crack length is demonstrated. The changes in the coating's effective thermal conductivity can be used to quantitatively describe the evolution of the delamination crack propagation and coating spallation behavior.

\section{TBC Buckling, Spallation and Critical Failure Strains}

Under the relatively low heat flux laser thermal cycling of thin coatings, the coating failure mode was found to be primarily coating delamination crack growth with eventual buckling spallation. Figure 3 shows crack lengths and the corresponding crack propagation rates of several laser tested TBC specimens as a function of cycle number. For the specimen tested, the initial average crack propagation rate was in the range of 3 to $8 \mu \mathrm{m} /$ cycle. However, the crack propagation increased significantly with further laser cycling. At the later stage near the coating spallation, the crack propagation rates increased to as high as 30 to $40 \mu \mathrm{m} /$ cycle. A mixed coating delamination crack propagation path (either in the ceramic near the ceramic/bond coat interface or in the thermally grown oxide scales) was observed for the tested specimens. The accelerated crack growth under laser heat flux cyclic conditions is attributed to the increased driving force (the increased thermal stresses) for the crack propagation. A critical crack size can be reached to initiate catastrophic coating spallation from the subcritical crack propagation during laser thermal cyclic loading exposure.

The critical buckling-spallation crack size, $2 a$ (the diameter of an approximate pennyshaped delamination crack), can be determined from the crack size plots (Fig. 3 ) at the coating spallation point. The critical crack size for initiating spallation was found to be in the range of 3 to $5 \mathrm{~mm}$. However, the final spallation size for the coating ranged from 5 to $12 \mathrm{~mm}$ after the laser cyclic testing, due to the fast, unstable crack propagation after the initial spallation. The critical spallation size as a function of coating thickness was plotted in Fig. 4. It can be seen that a larger critical crack size is needed to spall a thicker coating. For simplicity purpose and without considering the complex nature of thermal visco-plasticity behavior of the TBC system, the critical coating buckling spallation strain can be estimated from the classical elastic theory for a clamped circular plate [16]

$$
\sigma_{\text {spall }} / \mathrm{E}=\left[\kappa / 12\left(1-v^{2}\right)\right](t / a)^{2}
$$


where $\sigma_{\text {spait }}$ is the critical buckling/spallation stress, E and $v$ are Young's modulus and Poisson's ratio of the coating, respectively, $\kappa$ is a constant about $14.68, t$ is the coating thickness, and $a$ is the crack radius at the spallation. The compressive, critical spallation strain is about 0.8 percent for the plasma-sprayed thermal barrier coatings under the laser test conditions. This failure strain can correspond to a compressive spallation stress possibly ranging from 240 to $480 \mathrm{MPa}$, depending on the actual elastic modulus of the coatings. The laser test results are in good agreement with uniaxial compression test results $[6,11]$.

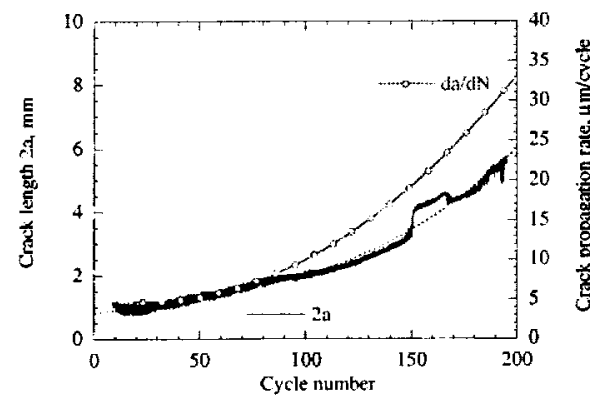

(a)

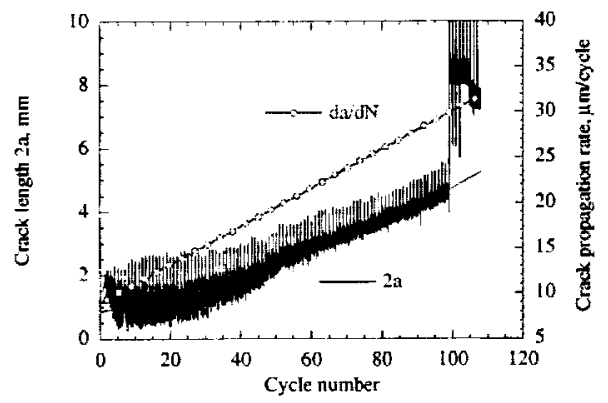

(c)

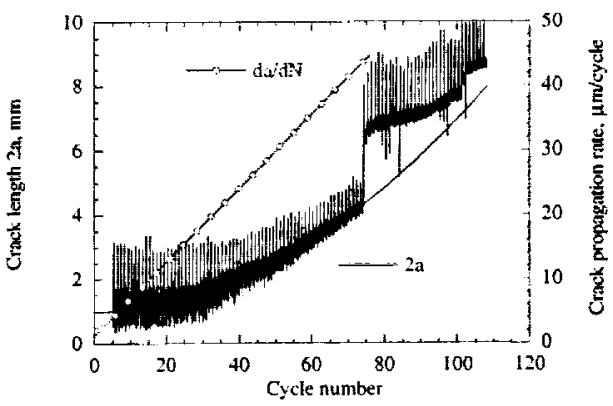

(b)

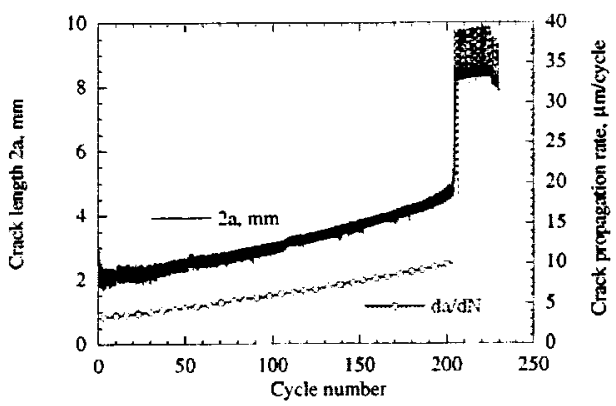

(d)

Fig. 3 Crack lengths and the corresponding crack propagation rates of laser tested TBC specimens as a function of cycle number. The crack propagation rates increase with the cycle number. The accelerated crack growth under laser heat flux cyclic conditions is attributed to the increased driving force for the crack propagation. (a) $127 \mu \mathrm{m}$-thick coating; (b) $176 \mu \mathrm{m}$-thick coating; (c) $185 \mu \mathrm{m}$-thick coating; (d) $200 \mu \mathrm{m}$-thick coating. 


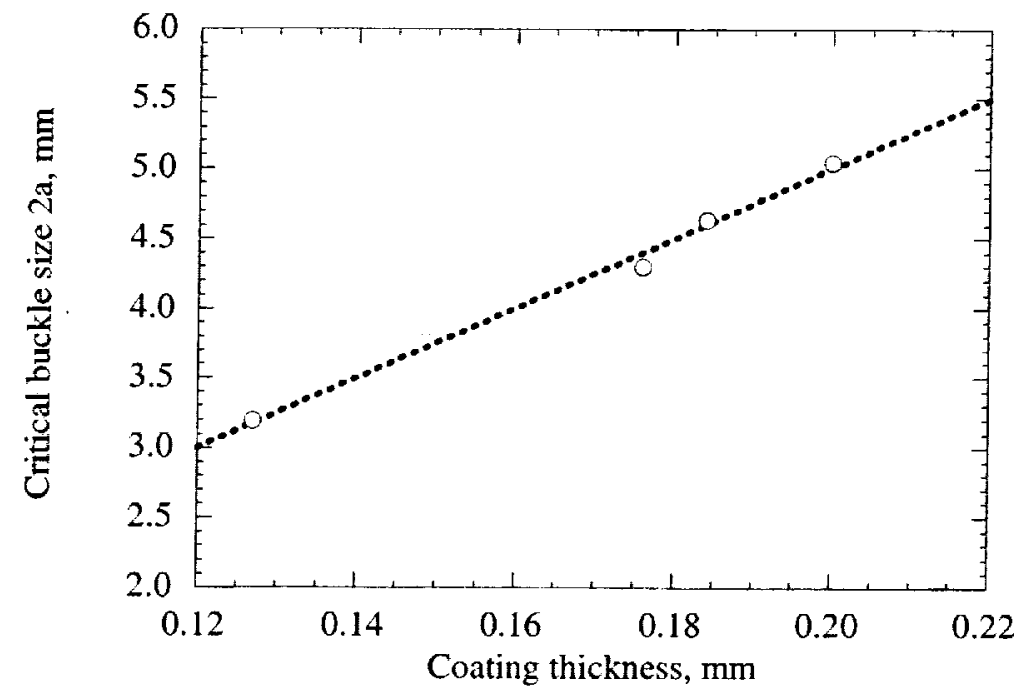

Fig. 4 The critical spallation size of the $\mathrm{ZrO}_{2}-8 \mathrm{wt} \% \mathrm{Y}_{2} \mathrm{O}_{3}$ coatings as a function of coating thickness under laser heat flux testing.

\section{Fatigue Crack Subcritical Growth}

The delamination crack propagation rate $d a / d N$ under the laser thermal cyclic loads can be generally expressed as

$$
d a / d N=d a / d N_{\text {heating }}+d a / d N_{\text {cooling }}=C_{1} \Delta K_{\text {heatung }}^{m}+C_{2} \Delta K_{\text {cooting }}^{m}
$$

where $d a / d N_{\text {heating }}$ and $d a / d N_{\text {cooling }}$ are the crack propagation rates under laser thermal transient heating and cooling, respectively, $\Delta K_{\text {heating }}$ and $\Delta K_{\text {cooling }}$ are the stress intensity factor amplitudes associated with the heating and cooling thermal loads, $C_{1}, C_{2}$ and $m$ are constants. Under the laser heat flux test conditions, due to the relatively large temperature difference $(\Delta T)$ across the ceramic coating, the residual compressive stresses for driving the coating delamination crack propagation are greatly reduced as compared to a uniform heating-cooling case. On the other hand, the dynamic transient thermal stresses, induced during the laser surface rapid heating of the partially delaminated coating may become a predominant driving force for the crack propagation, primarily because of the large thermal compressive stress magnitudes and the fast dynamic loading characteristics near the crack tip. Previous dynamic fatigue tests of the plasma-sprayed $\mathrm{ZrO}_{2}-8 \mathrm{wt} \% \mathrm{Y}_{2} \mathrm{O}_{3}$ have shown that the coating fracture stress is significantly reduced with increasing the loading stress rate. This phenomenon has been attributed to the reduced crack tip visco-plasticity induced blunting under the high stress rates [11].

In this study, in order to assess the effect of the thermal stress intensity factor amplitude $\Delta K$ on coating crack propagation, a coating delamination and buckling spalling model was used [17]. Based on the stress amplitude derived from the measured transient temperature profiles of the coating system, the subcritical crack propagation driving force $\Delta K$ can be estimated

$$
\Delta K=[(1-\alpha) /(1+v)]^{1 / 2}\left[1-\left(\sigma_{c} / \Delta \sigma_{t}\right)^{2}\right]^{1 / 2} \Delta \sigma_{t} t^{1 / 2}
$$


where $\alpha$ is a constant and $\alpha=0.399$ if taking $v=0.25, \Delta \sigma_{t}$ is the transient stress associated stress amplitude, $\sigma_{c}$ is the post-buckling stress in the coating. In general, $\sigma_{c} \ll \Delta \sigma_{r}$ under the laser high temperature test conditions. Note that the stress intensity factor amplitude, $\Delta K$, increases with laser thermal cycle number, because of the increased temperature difference $\Delta \sigma_{t}$, with increasing coating crack length $2 a$. Figure 5 illustrates the relationship between the delamination crack propagation rate $d a / d N$ and the laser thermal transient stress associated stress intensity factor amplitude $\Delta K$, during the laser thermal fatigue testing. The exponent, $m$, for the delamination fatigue crack growth under the laser thermal cycle driving force $\Delta K$, was found to be about 5 . Lower $m$ values were observed under larger $\Delta K$ conditions, which may be related to the complexity of the coating delamination-buckeling mechanism under the laser thermal gradient testing. Fig. 6 shows micrographs of laser thermal fatigue tested TBC specimens. As shown in Fig. 6(a), severe fatigue damages are observed near the early crack propagation wake surfaces with strong coating asperity/debris interactions and coating multiple delaminations under the laser thermal cyclic loading. However, the later crack paths show relatively smooth surfaces, which corresponds to the faster crack propagation regions under the increased crack propagation driving force. A coating spallation morphology after the laser thermal fatigue test is shown in Fig. 6(b).

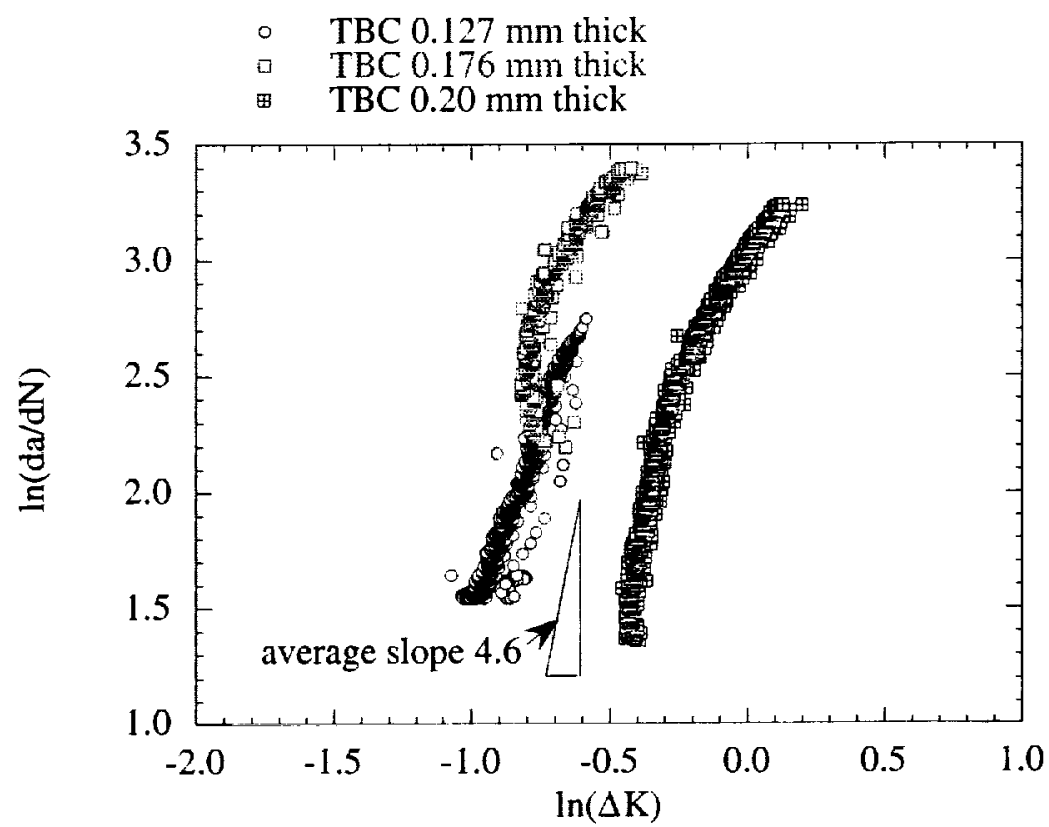

Fig. 5 The relationship between the delamination crack propagation rate $d a / d N$ and the laser thermal stress associated stress intensity factor amplitude $\Delta K$. 


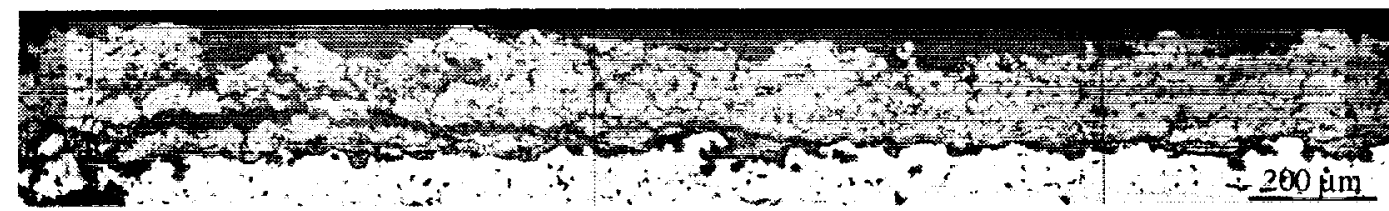

(a)
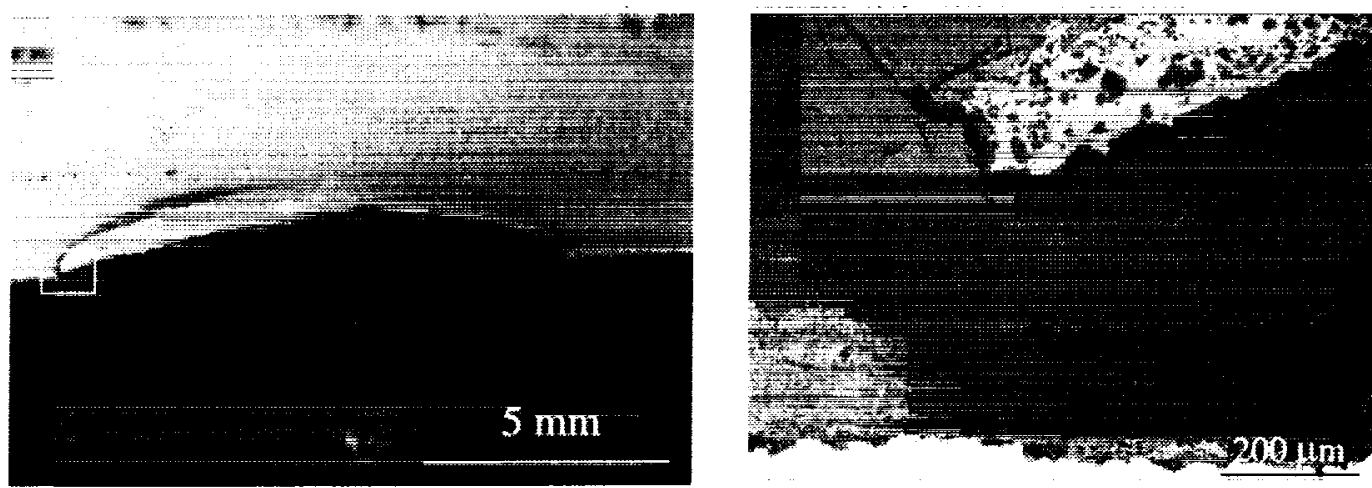

(b)

Fig. 6 Micrographs of laser thermal fatigue tested TBCs showing the coating delamination crack propagation and coating spallation. (a) Severe fatigue damages are observed near the early crack propagation wake surfaces with strong coating asperity/debris interactions and coating multiple delaminations under the laser thermal cyclic loading. The later crack paths show relatively smooth surfaces, which corresponds to the faster crack propagation regions under the increased crack propagation driving force. (b) Coating spallation morphology after the laser thermal fatigue test.

\section{CONCLUSIONS}

A laser thermal fatigue test technique has been used to study the delamination crack propagation of thermal barrier coatings under the heat flux heating and thermal cyclic loading. For the $\mathrm{ZrO}_{2}-8 \mathrm{wt} \% \mathrm{Y}_{2} \mathrm{O}_{3}$ coating specimen tested, the initial average crack propagation rate was in the range of 3 to $8 \mu \mathrm{m} /$ cycle. The crack propagation rates increased to 30 to $40 \mu \mathrm{m} / \mathrm{cycle}$ at the later stage of the tests. The coating spallation failure mode was observed, and the critical spalling crack size ranged from 3 to $5 \mathrm{~mm}$ for the TBC coatings. The accelerated crack growth is attributed to the increased driving force for the crack propagation under the laser heat flux cyclic test conditions.

\section{REFERENCES}

[1] D. Zhu and R.A. Miller, "Sintering and Creep Behavior of Plasma-Sprayed Zirconia and Hafnia-Based Thermal Barrier Coatings," Surface and Coatings Technology, vol. 108109, pp. 114-120, 1998.

[2] D. Zhu and R.A. Miller, "Determination of Creep Behavior of Thermal Barrier Coatings under Laser Imposed High Thermal and Stress Gradient Conditions," Journal of Materials Research, vol. 14, pp. 146-161, 1999.

[3] D. Zhu and R.A. Miller, "Thermal Barrier Coatings for Advanced Gas-Turbine Engines," MRS Bulletin, vol. 27, pp. 43-47, 2000.

[4] D. Zhu, R.A. Miller, B.A. Nagaraj, and R.W. Bruce, "Thermal Conductivity of EB-PVD Thermal Barrier Coatings Evaluated by a Steady-State Laser Heat Flux Technique," NASA Glenn Research Center, Cleveland, NASATM-2000-210238, July 2000. 
[5] D. Zhu and R.A. Miller, "Thermal Conductivity and Elastic Modulus Evolution of Thermal Barrier Coatings Under High Heat Flux Conditions," Joumal of Thermal Spray Technology, vol. 9, pp. 175-180, 2000.

[6] E.F. Rejda, D.F. Socie, and M.B. Beardsley, "Fatigue Behavior of A Plasma-Sprayed 8\% $\mathrm{Y}_{2} \mathrm{O}_{3}-\mathrm{ZrO}_{2}$ Thermal Barrier Coating," Fatigue Fract. Eng. Mater. Struct., vol. 20, pp. 1043-1050, 1997.

[7] T.A. Cruse, B.P. Johnsen, and A. Nagy, "Mechanical Properties Testing and Results for Thermal Barrier Coatings," Journal of Thermal Spray Technology, vol. 6, pp. 57-66, 1997.

[8] G. Thurn, G.A. Schneider, and F. Aldingger, "High Temperature Deformation of PlasmaSprayed $\mathrm{ZrO}_{2}$-Thermal Barrier Coatings," Mater. Sci. Eng., vol. A233, pp. 176, 1997.

[9] S.R. Choi, D. Zhu, and R.A. Miller, "High-Temperature Slow Crack Growth, Fracture Toughness and Room-Temperature Deformation Behavior of Plasma-Sprayed $\mathrm{ZrO}_{2^{-}}$ $8 \mathrm{wt} \% \mathrm{Y}_{2} \mathrm{O}_{3}, "$ Ceramic Eng. Sci. Proc., vol. 19, pp. 293-301, 1998.

[10] C.A. Johnson, J.A. Ruud, R. Bruce, and D. Wortman, "Relationships between Residual Stress, Microstructure and Mechanical Properties of Electron Beam-Physical Vapor Deposition Thermal Barrier Coatings," Surface and Coatings Technology, vol. 108-109, pp. 80-85, 1998.

[11] S.R. Choi, D. Zhu, and R.A. Miller, "Flexural and Compressive Strength, and RoomTemperature Creep/Relaxation Properties of Plasma-Sprayed $\mathrm{ZrO}_{2}-8 \mathrm{wt} \% \mathrm{Y}_{2} \mathrm{O}_{3}$," Ceram. Eng. Sci. Proc., vol. 20, pp. 365-372, 1999.

[12] E.F. Rejda, D.F. Socie, and T. Itoh, "Deformation Behavior of Plasma-Sprayed Thick Thermal Barrier Coatings," Surface and Coatings Technology, vol. 113, pp. 218-226, 1999.

[13] D. Zhu and R.A. Miller, "Thermal Conductivity and Elastic Modulus Evolution of Thermal Barrier Coatings Under High Heat Flux Conditions," NASA Glenn Research Center, Cleveland, Ohio, NASA TM-209069, 1999.

[14] D. Zhu and R.A. Miller, "Thermophysical and Thermomechanical Properties of Thermal Barrier Coating Systems," Ceram. Eng. Sci. Proc., vol. 21, pp. 623-633, 2000.

[15] D. Zhu, A.M. Calomino, and R.A. Miller, "Real-Time Thermal Conductivity and Delamination Mechanisms of Plasma-Sprayed Thermal Barrier Coatings under HighHeat-Flux Conditions," in International Conference on Metallurgical Coatings and Thin Films, San Diego, in press, 2001.

[16] S. Timoshenko and J.M. Gere, Theory of Elastic Stability, 2nd Edition ed. New York: McGraw Hill, 1961.

[17] A.G. Evans and J.W. Hutchinson, "On the Mechanics of Delamination and Spalling in Compressed Films," International Journal of Solids and Structures, vol. 20, pp. 455-466, 1984. 
Public reporting burden for this collection of information is estimated to average 1 hour per response, including the time for reviewing instructions, searching existing data sources. gathering and maintaining the data needed, and completing and reviewing the collection of information. Send comments regarding this burden estimate or any other aspect of this collection of information, including suggestions for reducing this burden, to Washington Headquarters Services, Directorate for Information Operations and Reports, 1215 Jefferson Davis Highway, Suite 1204, Artington, VA 22202-4302, and to the Office of Management and Budget, Paperwork Reduction Project (0704-0188), Washington, DC 20503.

\begin{tabular}{|l|l|l|}
\hline 1. AGENCY USE ONLY (Leave blank) & 2. REPORT DATE & 3. REPORT TYPE AND DATES COVERED
\end{tabular}

\section{TITLE AND SUBTITLE} June 2001

Technical Memorandum

Thermal Fatigue and Fracture Behavior of Ceramic Thermal Barrier Coatings

6. AUTHOR(S)

WU-714-04-20-00

Dongming Zhu, Sung R. Choi, and Robert A. Miller

7. PERFORMING ORGANIZATION NAME(S) AND ADDRESS(ES)

National Aeronautics and Space Administration

John H. Glenn Research Center at Lewis Field

Cleveland, Ohio 44135-3191

5. FUNDING NUMBERS

9. SPONSORINGMONITORING AGENCY NAME(S) AND ADDRESS(ES)

10. SPONSORINGMONITORING

National Aeronautics and Space Administration

Washington, DC 20546-0001

8. PERFORMING ORGANIZATION

REPORT NUMBER

E-12731 AGENCY REPORT NUMBER

NASA TM-2001-210816

11. SUPPLEMENTARY NOTES

Prepared for the 25th Annual International Conference on Advanced Ceramics and Structures sponsored by the American

Ceramic Society, Cocoa Beach, Florida, January 21-26, 2001. Dongming Zhu and Sung R. Choi, Ohio Aerospace

Institute, 22800 Cedar Point Road, Brook Park, Ohio 44142, and Robert A. Miller, NASA Glenn Research Center.

Responsible person, Robert A. Miller, organization code 5160, 216-433-3298.

12a. DISTRIBUTIONAVAILABILITY STATEMENT

12b. DISTRIBUTION CODE

Unclassified - Unlimited

Subject Categories: 24 and 27

Distribution: Nonstandard

Available electronically at http:/gltrs.grc, nasa.gov/GLTRS

This publication is available from the NASA Center for AeroSpace Information, 301-621-0390.

13. ABSTRACT (Maximum 200 words)

Thermal fatigue and fracture behavior of plasma-sprayed ceramic thermal barrier coatings has been investigated under high heat flux and thermal cyclic conditions. The coating crack propagation is studied under laser heat flux cyclic thermal loading, and is correlated with dynamic fatigue and strength test results. The coating stress response and inelasticity, fatigue and creep interactions, and interface damage mechanisms during dynamic thermal fatigue processes are emphasized.

\section{SUBJECT TERMS}

Thermal barrier coatings; Thermal fatigue; Thermal conductivity; Coating delaminations

17. SECURITY CLASSIFICATION OF REPORT

Unclassified
18. SECURITY CLASSIFICATION OF THIS PAGE Unclassified
19. SECURITY CLASSIFICATION OF ABSTRACT Unclassified
15. NUMBER OF PAGES 15

16. PRICE CODE

20. LIMITATION OF ABSTRACT

Standard Form 298 (Rev. 2-89)

Prescribed by ANSI Std. Z39-18 298-102 